\author{
S. Jayaraj $^{1^{*}}$, A. James ${ }^{1}$, M. Srinivas ${ }^{1}$ and M. Mohanraj ${ }^{2}$ \\ ${ }^{1}$ National Institute of Technology, Kerala, India \\ ${ }^{2}$ Hindustan College of Engineering and Technology, Tamil Nadu, India \\ "e-mail: sjayaraj@nitc.ac.in
}

\title{
Energy-Efficient Operation of PV-T Solar Collectors with Heat Pump based Water Heaters Suitable for Domestic Applications
}

\begin{abstract}
A photovoltaic-thermal (PV-T) hybrid collector evaporator was designed and developed to produce electrical energy and extract thermal energy simultaneously from the panel using the refrigerant circulated the evaporator tubes. The refrigerant absorbs the heat from photovoltaic panels during its phase change from liquid to vapour. The PV-T evaporators deliver both electricity and heat outputs. An R-32 refrigerant-based solar-assisted heat pump water heating system with a rated heat output of $4 \mathrm{~kW}$ was developed and tested its performance for producing 150-200 litres of hot water at an average temperature of $60^{\circ} \mathrm{C}$. The R-32 refrigerant is selected because it does not have any ozone depletion potential (ODP), and possess very low global warming potential (GWP). The heat pump evaporator was designed to absorb 3.25 $\mathrm{kW}$ heat from the panel and maintains the panel below $30^{\circ} \mathrm{C}$. The average PV electricity output was $6 \mathrm{kWh}$, and the requirement was $3.5 \mathrm{kWh}$. The average excess power of $2.5 \mathrm{kWh}$ has been supplied to the grid, and the average coefficient of performance (COP) of the system was 6.3. For a life span of 25 years, the total equivalent warming impact analysis (TEWI) resulted in a $\mathrm{CO}_{2}$ value of $15,543 \mathrm{~kg}$, which is very much lower than that of conventional systems. The economic analysis performed was reported, and the system is found to be quite suitable for domestic applications and also economically feasible with a payback period of 2.5 years.
\end{abstract}

Key words: Solar PV-T Collectors, VFD Compressor, Domestic Water Heating.

\section{Introduction}

The present renewable energy market is experiencing a rapid development owing to the sophisticated technologies emerging with higher overall system efficiencies. The widely used renewable energy capturing technology is the solar photovoltaic (PV) cells. But, the commercially available solar PV cells have only a low range of conversion efficiency. In the range of $15-20 \%$ and the remaining is getting wasted and contributing to cell temperature increase, conversion efficiency decreases. So, it would be beneficial to the conversion efficiency if we can absorb some portion of the wasted energy through some other technology. The $\mathrm{PV}$ technology gained more attention during the last three decades as more and more governmental as well as global environmental policies were evolved and instructed the usage of various renewable energy technologies. Solar PV technology is considered to be widely infamous because of the smaller conversion efficiency involved. The commercial conversion efficiency range of $15-20 \%$ is further reduced, if the panel is intended to work where the ambient temperature is above $25^{\circ} \mathrm{C}$. The reduction in cell efficiency is so rapid concerning the temperature increase above this optimum value. The major part of the incoming radiation that is escaping in the form of thermal energy can be extracted for the purpose of drying and water or space heating. This thought paved the way to the invention of such hybrid photovoltaic-thermal (PV-T) collectors. The first PV-T collector technology was introduced in the year 1978 by Kern and Russel [1]. It succeeded in providing a combined output of electrical energy and thermal energy with the space requirement of one system.

Further, the initial theoretical model of airbased and liquid-based PV-T hybrid collectors was developed [2] based on the extended Hottel- 
Whillier-Bliss model [3] by considering the PV conversion efficiency as a linear function of PV cell operating temperature. The design considerations of monocrystalline Silicon cell-based PV-T collectors were formulated. The correlation between various design parameters was identified, especially in the effect of glazing and its transmissivity and emissivity values [4]. During the next decade, several studies were reported in combined collectors, and most of them are of hybrid PV-T air collector arrangements. A novel PV-T collector configuration that can spectrally split the incoming radiation using some radiation beam splitters was proposed and performed simulation study with various operating conditions [5]. The electrical output from such a collector system is found reduced than the conventional system, and that reduction is compensated in the thermal output generated. The PV-T hybrid collector technology was developed further using different and more efficient heat transferring fluids and methods. The various configurations can be categorized into six major categories, i.e., air-based PV-T collectors, liquid-based PV-T collectors, nanofluid based PV-T collectors, heat pipe assisted PV-T collectors, phase change material (PCM) based PV-T collectors, and refrigerant-based heat pump PV-T collectors. Numerous significant studies [6]-[19] were reported in the last two decades explaining the developments in these six configurations for overall system efficiency improvement.

As the refrigerant-based heat pump PV-T collector systems have comparatively higher overall system efficiency than the other configurations, most of the further PV-T collector investigations report in that domain [6]-[8]. In the present work, the R-32 refrigerant-based heat pump PV-T collector is working as the evaporator section. The refrigerant flowing through the copper tubes attached to the bottom of the PV panel and extracting the waste heat available after the photoelectric conversion of the incoming radiation and by this extraction the operating temperature of the PV cells reduces efficiency improves. The heat pump rejects the extracted thermal energy at the condenser to the water in the surrounding tank, and thereby the hot water becomes available for domestic applications. The novelty of this work is the use of a variable frequency drive (VFD) compressor (which works by following the load available at the evaporator exit). The VFD compressor operates in place of a conventional compressor, and thereby increase in energy efficiency is obtained.

\section{Experimental Setup}

Investigations were performed under the meteorological conditions of Calicut $\left(11.25^{\circ} \mathrm{N}\right.$, $75.78^{\circ} \mathrm{E}$ ), India. Three $330 \mathrm{~W}_{\mathrm{e}}$ polycrystalline panels were used as the base plant, and a heat pump circuit was designed to absorb $3 \mathrm{~kW}$ heat from the PV panels. The R-32 refrigerant is selected as the working fluid since it has no ozone depletion potential (ODP) and the global warming potential is only 650 (it is around $1 / 3^{\text {rd }}$ of R-22). Experiments were performed from 08:00 hrs to 18:00 hrs, and clear sky days were only considered for the analysis.

The schematic representation of the VFD compressor heat pump assisted PV-T hybrid collector-based water heating system is shown in Fig. 1. The heat pump circuit of the experimental system is made up of $3 / 8$ " copper tubes, and evaporator circuits are arranged in parallel through the bottom of the three panels. The temperature of the refrigerant available at the evaporator exit is continuously monitoring, and the frequency of the compressor is varying in accordance with that load values. The compressor runs continuously for a few minutes, in the beginning, to develop enough pressure in the refrigerant circuit and then become idle and work only according to the feedback signal. The photograph of the heat pump-based PV-T hybrid collector water heating system installed at the Solar Energy Centre (SEC), National Institute of Technology, Calicut, is shown in Fig. 2.

The temperature and pressure values from the various locations of the heat pump circuit and water tank were continuously monitored using a data logger. The theoretical analyses based on the first and second laws of thermodynamics were performed based on the experimental data obtained for the different testing days [9]. 


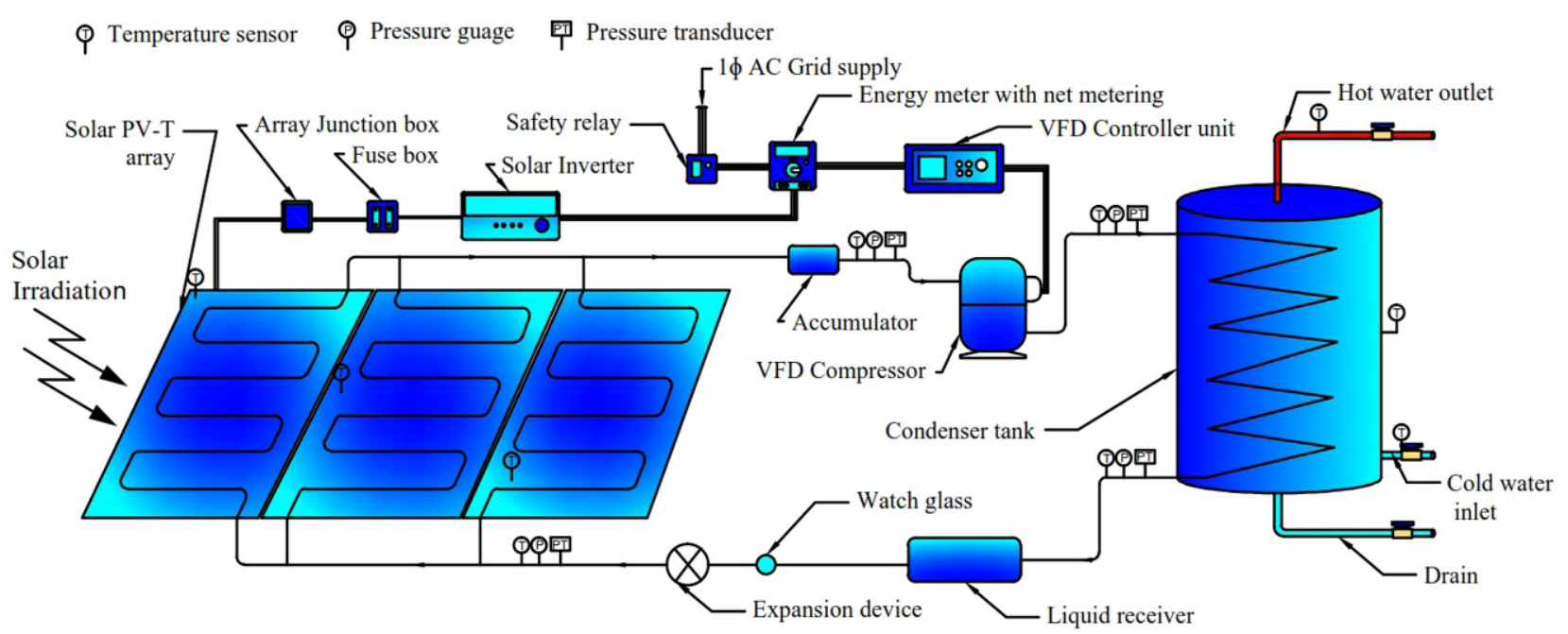

Figure 1 - Schematic representation of the heat pump-based PV-T water heating setup

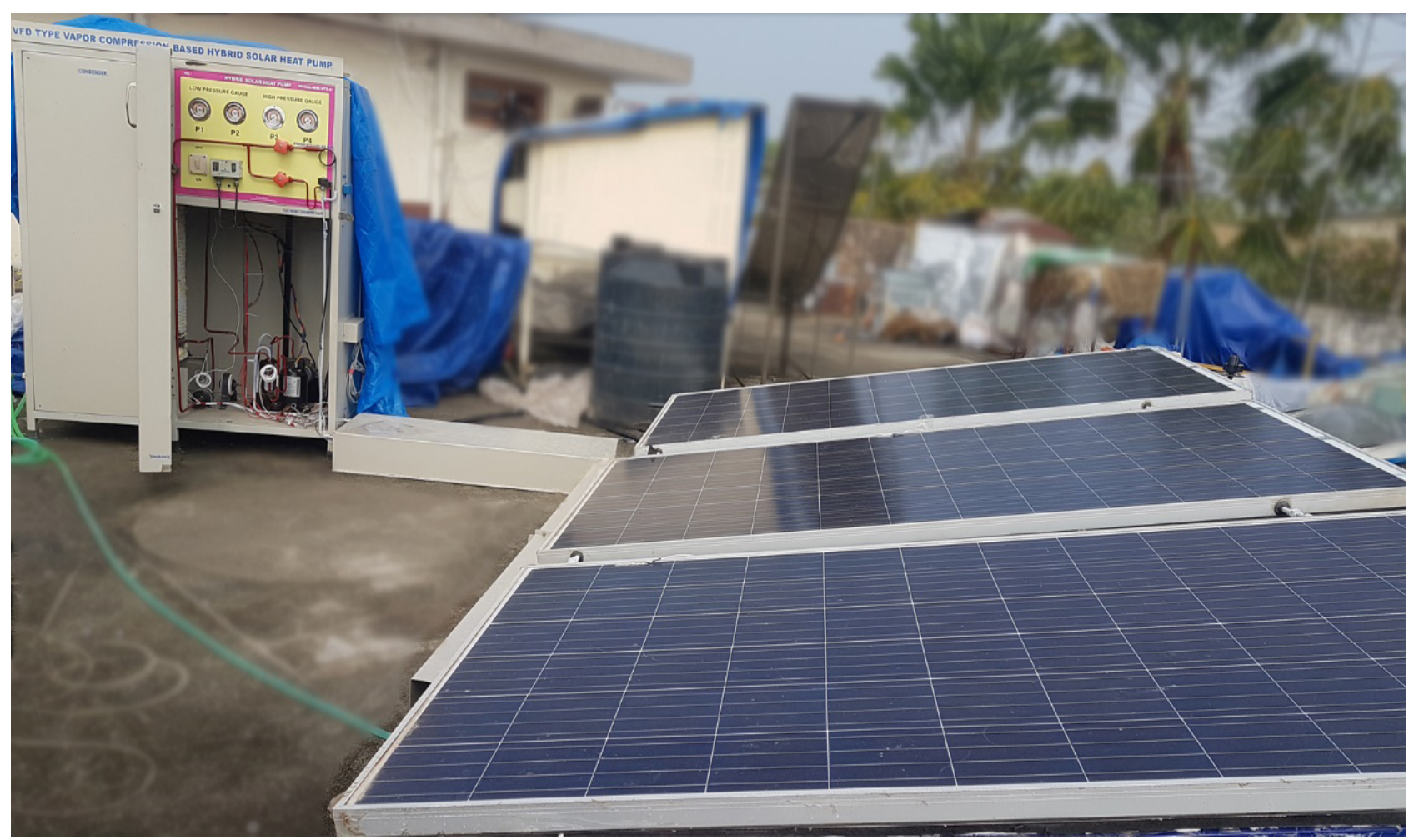

Figure 2 - Photographic view of the heat pump-based PV-T water heater system installed at the SEC

\section{Results and Discussions}

During the testing days, the solar irradiations varied from $140 \mathrm{~W} / \mathrm{m}^{2}$ in the morning to the maximum irradiation value of $770 \mathrm{~W} / \mathrm{m}^{2}$ by noon. Even though it reached $2 \mathrm{~W} / \mathrm{m}^{2}$ at 17:45 hrs, the variation was almost entirely in a pattern without significant fluctuations.
The ambient temperature and the PV panel temperature are found to vary in accordance with the solar irradiation changes. Ambient temperature variation was from $28^{\circ} \mathrm{C}$ to $34^{\circ} \mathrm{C}$. The PV panel temperature of the standard panel kept without cooling is varied from $30^{\circ} \mathrm{C}$ to $65^{\circ} \mathrm{C}$, whereas that of panel cooled using heat pump showed a maximum temperature value of Int. j. math. phys. (Online) 
$45^{\circ} \mathrm{C}$ only. The characteristics of the variation of PV temperature with and without cooling according to the variations of solar irradiation and ambient temperature are shown in Fig. 3. The operating temperature of the
PV panel showed a near-linear pattern variation since the waste heat generated is efficiently getting removed by the heat pump circuit integrated to the bottom of the panels.

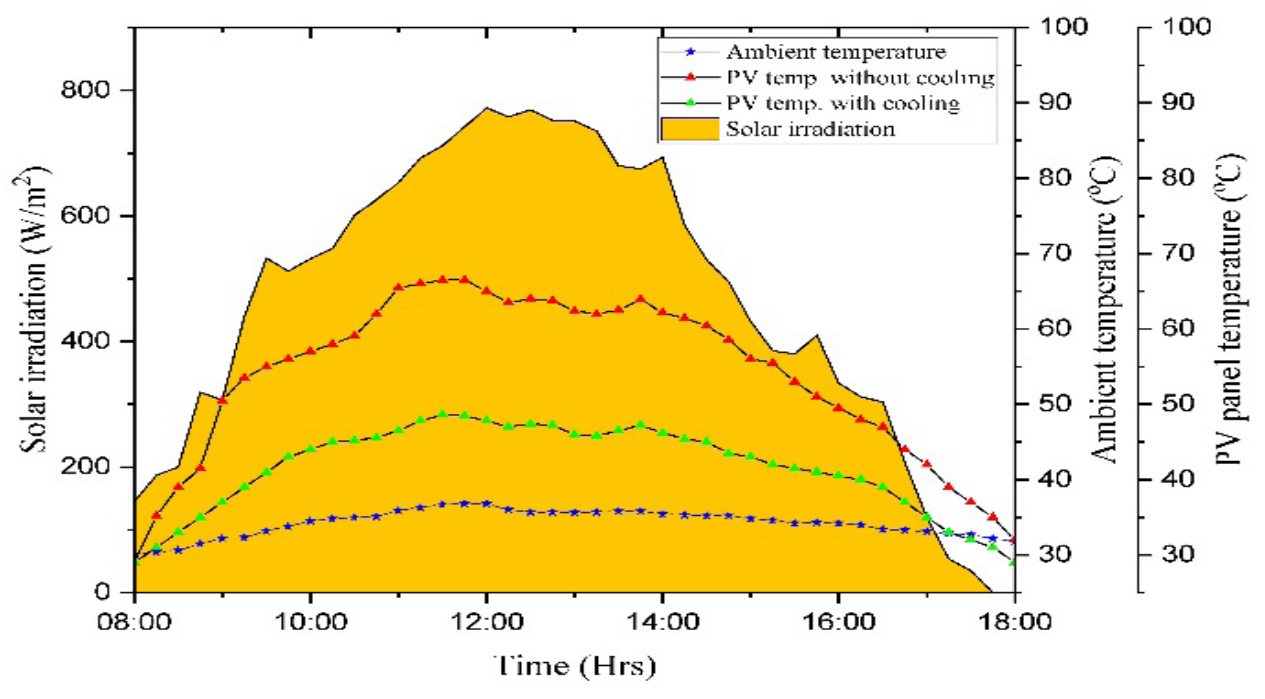

Figure 3 - Characteristics of PV temperature variation with solar irradiation and ambient temperature

In the case of the electrical power output from the PV panels, the panels integrated with heat pump cooling produce an average of $7.5 \mathrm{kWh}$ of electricity during a clear sky day, and that is around $1 \mathrm{kWh}$ higher than what was available from the standard panel kept without cooling for comparison purpose. That is happened because of the improved conversion efficiency of the PV cells achieved through heat pump-based cooling. The variation in the current and the voltage with and without cooling are shown in Figs. 4 and 5. The current output from the cooled PV panels showed significant improvement than the current made available from the reference PV panel kept without cooling. The voltage values are also showed substantial improvement with heat pumpbased cooling. The voltage from the cooling panels is found to be varied from $55 \mathrm{~V}$ to $72 \mathrm{~V}$ without cooling, and that varied from $58 \mathrm{~V}$ to $79 \mathrm{~V}$ with the application of the cooling.

Since the operating temperature of the PV cells was able to be kept without much increase, the conversion efficiency of the PV cells also gets increased than that of the reference panel and which results in a significant hike in the electrical power output available from the PV panels. The characteristics of the electrical power output with and without cooling are shown in Fig. 6. An average improvement of $15 \%$ is observed in the total power output. Simultaneously, the input power requirement of the VFD compressor is comparatively lesser than that of the conventional compressor. Thus, the power consumption for the system reduces significantly. So, the VFD compressor integrated heat pump-based cooling contributes enough to the net power output from the system.

The COP of the system was found to be varied between 1.5 and 9 and reported an average value of 6.2 with the refrigerant R-32. The electrical PV efficiency and thermal energy efficiency are increased significantly and reached maximum values of $17 \%$ and $80 \%$ at some instants of the total experiment duration. The $17 \%$ electrical PV efficiency is very nearer to the standard conversion efficiency of the selected PV polycrystalline PV panel. The economic analysis performed also resulted in a payback period of 2.5 years, which is very much lower than that of PV-T water heating systems with conventional compressors. Thus, the developed heat pump cooled hybrid PV-T collector-based water heater is found feasible performance-wise and cost-wise. 


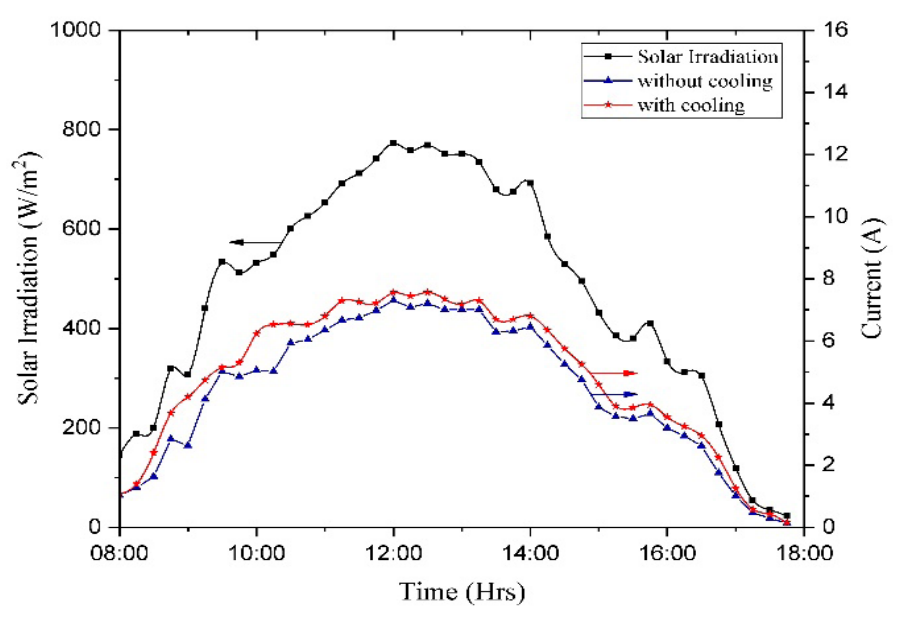

Figure 4 - Variation of current output with and without cooling

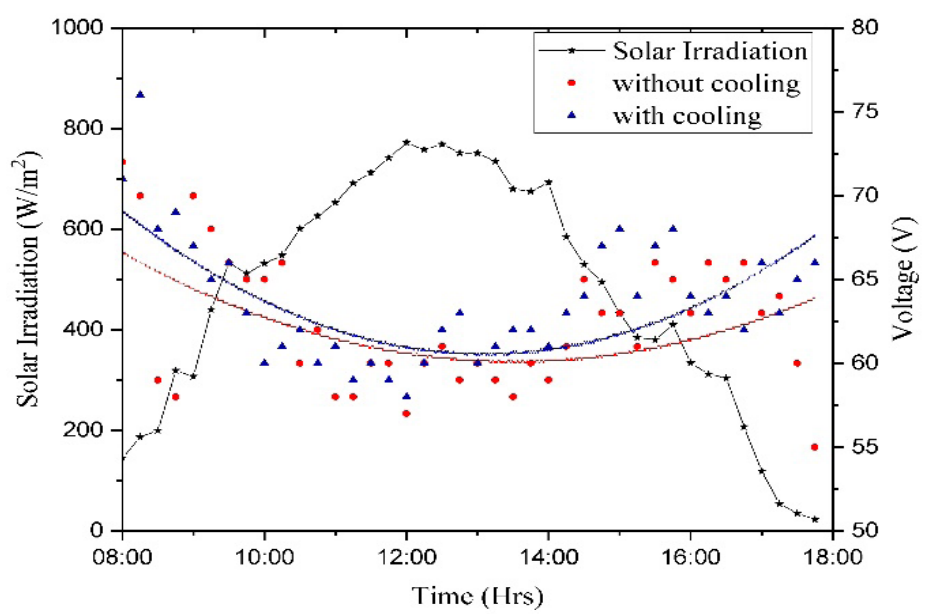

Figure 5 - Variation in the output voltage with and without cooling

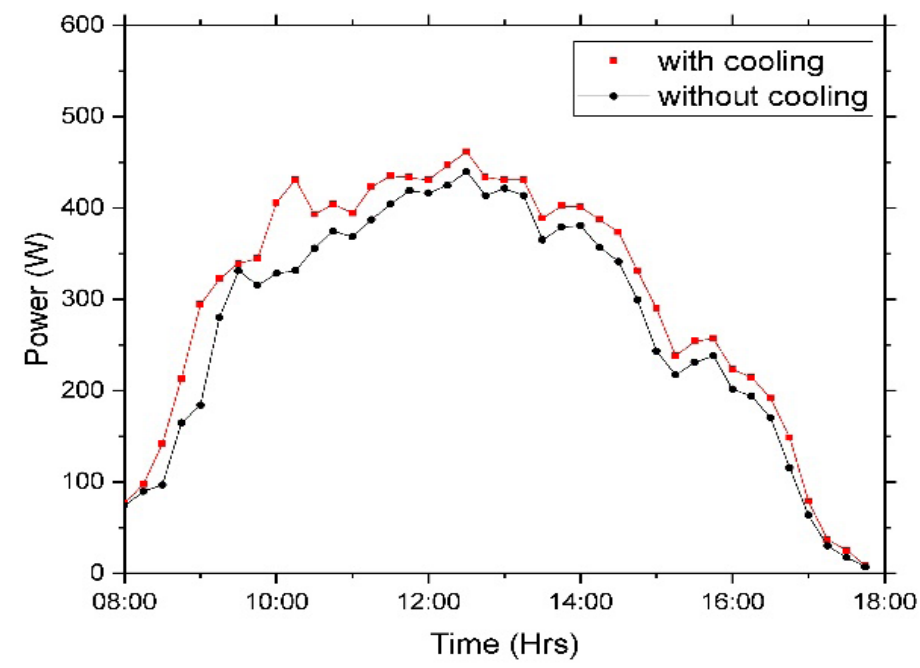

Figure 6 - Characteristics of the electrical power output from the panels with and without cooling

Int. j. math. phys. (Online)

International Journal of Mathematics and Physics 12, №1, 12 (2021) 


\section{Prototype Development}

The prototype of an ambient source heat pump water heater of $100 l$ capacity was developed and tested for its performance for residential water heating applications. The ambient source heat pump water heater consists of essential components such as a hermetically sealed compressor of rated power input of $1 \mathrm{~kW}$, immersion type condenser, capillary tube expansion device, and forced convection finned tube evaporator. The ambient source heat pump was charged with R134a. The refrigerant
$\mathrm{R} 134 \mathrm{a}$ has a high critical temperature of $106^{\circ} \mathrm{C}$. Hence, it is possible to operate the heat pump water heaters using R134a up to $75^{\circ} \mathrm{C}$. The photograph of the condenser tank, compressor and other control devices of the prototype developed are shown in Fig. 7. This heat pump water heater consumes $2-3 \mathrm{kWh}$ of electricity to produce 150 liters of hot water at $55^{\circ} \mathrm{C}$, which is significantly lower than conventional resistance water heating systems. The payback of the heat pump water heaters is around two years when compared to the electrical resistance water heating systems.

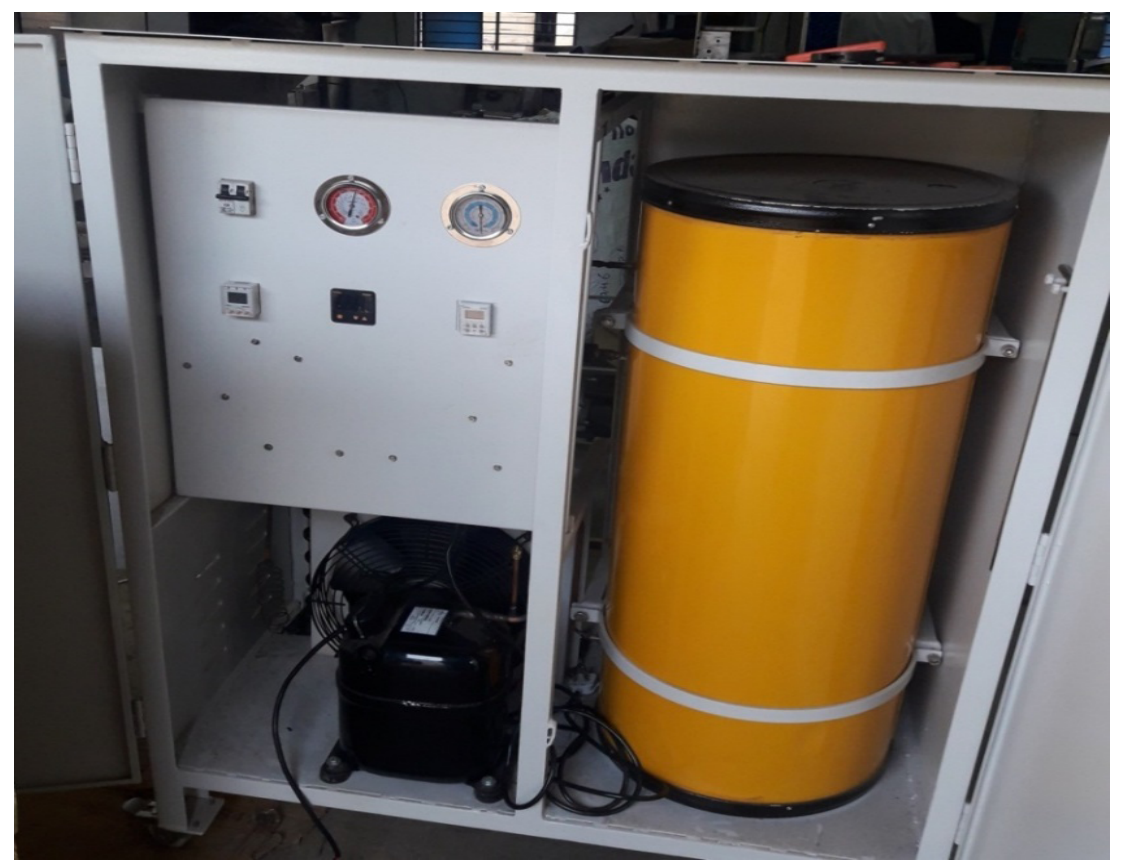

Figure 7 - Photographic view of prototype ambient source heat pump water heater

\section{Conclusions}

The VFD compressor integrated heat pumpbased PV-T water heating system was experimented with respect to its electrical, thermal, and overall system efficiency. The integration of a VFD compressor instead of the conventional compressor has reduced the compressor power requirement of the PV-T heat pump water heater system. The average operating temperature of the PV panels is reduced around $22 \%$ with heat pump cooling and which contributed to an output power enhancement of $15 \%$. The instantaneous thermal energy efficiency and PV efficiency are improved with cooling by $12 \%$ and $28 \%$, respectively. The thermal performance of the system improved with cooling and reported an average COP of 6.3 for the developed heat pump system with the integration of the VFD compressor. The average PV electricity output was $6 \mathrm{kWh}$, and the input power requirement for the compressor was $3.5 \mathrm{kWh}$. Thus, on an average about $2.5 \mathrm{kWh}$ can be supplied back to the utility on a daily basis. If we are developing it as a stand-alone system, with a $1 \mathrm{~kW}$ solar power plant and integrated heat pump water heating system, it is technically possible to generate around $3 \mathrm{kWh}$ of PV electricity and around 200 litres of hot water without grid-connected electricity. The system performance can be further improved using zeotropic refrigerant mixtures, as their non-linear behaviour will provide more uniform cooling to the panels. The economic analysis per- 
formed, and the system is found to be economically feasible with a payback period of 2.5 years.

\section{Acknowledgement}

This work is part of a Department of Science and Technology, Government of India funded research project titled "Development, testing and standardization of heat pump water heaters using solar photovoltaic-thermal hybrid evaporators" (Ref. No.: DST/ TMD/CERI/C47(G)).

\section{References}

1 E. C. Kern and M. C. Russell, "221 Makifr, Conf- 7806/7--," 13th IEEE Photovolt. Spec. Conf., no. June, 1978.

2 S. D. Hendrie, "Evaluation of combined photovoltaic/thermal collectors," 1979, no. June, pp. 790541-54.

3 L. W. Ft, "Extension of the Hottel-Whillier model to the analysis of combined photovoltaic/ thermal flat plate collectors," 22 (1979): 361-366.

4 C. H. Cox and P. Raghuraman, "Design considerations for flat-plate-photovoltaic/thermal collectors," Sol. Energy, vol. 35, no. 3 (1985): 227241, doi: 10.1016/0038-092X(85)90102-1.
5 M. A. Hamdy, F. Luttmann, and D. Osborn, "Model of a spectrally selective decoupled photovoltaic/thermal concentrating system," Appl. Energy, vol. 30, no. 3 ( 1988): 209-225, doi: 10.1016/0306-2619(88)90046-3.

6 G. Pei, J. Ji, T. T. Chow, H. He, K. Liu, and $\mathrm{H}$. Yi, "Performance of the photovoltaic solar-assisted heat pump system with and without glass cover in winter: a comparative analysis," Proc. Inst. Mech. Eng. Part A J. Power Energy, vol. 222, no. 2 (2008): 179-187, doi: 10.1243/09576509JPE431.

7 J. Ji et al., "Experimental study of photovoltaic solar assisted heat pump system," Sol. Energy, vol. 82, no. 1 (2008): 43-52, doi: 10.1016/j. solener.2007.04.006.

8 H. Hu, R. Wang, and G. Fang, "Dynamic characteristics modeling of a hybrid photovoltaicthermal heat pump system," Int. J. Green Energy, vol. 7, no. 5 (2010): 537-551, doi: 10.1080/15435075.2010.515446.

9 S. Jayaraj, A. James, M. Srinivas, and M. Mohanraj, "Experiments on a PVT based hybrid solar collector operated heat pump suitable for space heating in energy efficient buildings," ASHRAE 4th International Conference on Efficient Building Design. October 2020. 